\title{
Duygusal ve Kültürel Zekânın İş Tatmini ve Örgütsel Bağlılık Üzerindeki Etkisi: Sosyal Sermayenin Aracılık Rolü
}

\author{
Deniz ÇIPA ${ }^{1} \quad$ Mine AFACAN FINDIKLI ${ }^{2} \quad$ Erkut ALTINDAĞ ${ }^{3}$
}

Gönderim Tarihi: 31.07.2021

Kabul Tarihi: 26.09 .2021

Yayın Tarihi: 19.10 .2021

Öz: Bu ampirik çalışmanın temel amac1, öğretmenlerin duygusal ve kültürel zekâ düzeyinin iş tatmini ve örgütsel bağlılığa etkisini incelemek ve sosyal sermaye aracılığıyla bu etkinin farklılık gösterip göstermediğini ortaya koymaktır. Araştırma, nicel yöntemlerden açıklayıcı araştırma yöntemi kullanılarak yapılandırılmıştır. Araştırma evreni, 2018- 2019 akademik yılında İstanbul İlinde resmi ilkokul ve ortaokullarda görev yapan 64.673 öğretmenden oluşmaktadır. Araştırmanın örneklemini ise kartopu yöntemi ile seçilen 642 öğretmen oluşturmaktadır. Toplanan veriler, yapısal eşitlik modellemesi kapsamında Smart PLS kullanılarak test edilmiştir. Önceki araştırmalarda desteklenmiş olduğu görülmesine rağmen, bu araştırmada yer alan öğretmen örneklemi içerisinde duygusal ve kültürel zekânın iş tatmini üzerinde etkisi görülmemiştir. Diğer yandan duygusal zekânın duyguların düzenlenmesi boyutu ve motivasyonel kültürel zekâ boyutunun duygusal bağlllık ve devam bağllı̆̆ı üzerinde anlamlı ve pozitif yönlü bir etkiye sahip olduğu tespit edilmiştir. Sosyal sermaye, örgütsel bağlılık üzerinde doğrudan ve anlamlı bir etkiye sahiptir. Duygusal ile kültürel zekânın örgütsel bağlılık üzerindeki etkisinde sosyal sermayenin herhangi bir aracılık etkisi belirlenmemiştir.

Anahtar Kelimeler: Duygusal Zekâ, Kültürel Zekâ, Sosyal Sermaye, İş Tatmini, Örgütsel Bağlllık

\section{The Effect of Emotional and Cultural Intelligence on Job Satisfaction and Organizational Commitment: The Mediating Role of Social Capital}

\begin{abstract}
The main purpose of this empirical study is to examine the effect of teachers' emotional and cultural intelligence levels on job satisfaction and organizational commitment and to put forward whether this effect differs through social capital. The research is structured by using the explanatory research method which is a quantitative method. The population of the research consists of 64.673 teachers working in public schools in İstanbul province during the 20182019 academic year. The sample of the study consists of 642 teachers selected by snowball sampling method. The collected data were tested using the Smart PLS software under the Structural Equation Modeling. Although it is seen that the findings of previous studies support the correlation between the emotional and cultural intelligence and job satisfaction no impact of emotional and cultural intelligence on job satisfaction is observed according to the findings of this study based on the sampling of the teachers. On the other hand, it is observed that the regulation of emotional dimension of emotional intelligence and motivational dimension of cultural intelligence have a significant and positive impact on affective commitment and continuance commitment. Social capital has a direct and significant impact on organizational commitment. When examining the effects of emotional intelligence and cultural intelligence on organizational commitment, it is observed that social capital doesn't have an effect as a mediator.
\end{abstract}

Keywords: Emotional Intelligence, Cultural Intelligence, Social Capital, Job Satisfaction, Organizational Commitment

\section{GİRIŞ}

Çalışma yaşamının merkezinde öğrencileri olan, onları yaşama ve bir üst öğrenim kurumuna hazırlayan öğretmenlerin duygularından uzak bir şekilde mesleğini sürdürmesi mümkün değildir. Okulun dış çevresi, idareciler ve meslektaşlar ile yaşanan iletişim problemleri, sınıf yönetimi konusunda öğrenciler ile yaşanan bir takım sıkıntılar öğretmenlerin çalışma hayatlarında duygusal ve kültürel zekâlarını ön plana çıkarmalarını gerektirmektedir. Alanyazında duygusal zekâ, genel

Bu çalışma, Deniz ÇIPA'nın doktora tezi temel alınarak üretilmiştir.

${ }^{1}$ Beyoğlu Kadı Mehmet Ortaokulu, Türkiye, denizzz1610@hotmail.com, ORCID: 0000 - 0003 - 0232 - 7843

2 İstinye Üniversitesi, Türkiye, mine.findikli@istinye.edu.tr , ORCID: 0000 - $0003-1021$ - 6641

${ }^{3}$ Beykent Üniversitesi, Türkiye, erkutaltindag@beykent.edu.tr, ORCID: 0000 - 0003 - 0173 - 0454 
zekânın bir parçası olarak kabul edilmiş ve sosyal ortamda uyum için çok önemli görülmüştür. Bu görüşle paralel olarak sosyal durumlarda başarıya ulaşmak için kişilerin sıklıkla deneyimleri ve algıları vasıtasıyla edindikleri duygusal bilgileri kullanma eğiliminde oldukları öne sürülmüştür (Sale, 2014). Bu konudaki çalışmalar Gardner'in (1983) çoklu zekâ kavramını ortaya koymasıyla devam etmiştir. Gardner (aktaran Rust, 2014) 1983'te “Zihin Çerçeveleri” adlı kitabında, zekâ testleriyle ortaya koyulamayan içsel ve kişilerarası zekânın değerini vurgulamıştır. Duygusal zeka, yaşamda başarı için bilişsel kabiliyetin dışında kişinin hayatını devam ettirmesine katkıda bulunan başka faktörlerin de bulunduğunu (örneğin sosyal yeterlilikler, duygusal hassasiyet, duygusal uyum, motivasyon, öz-kontrol) ortaya koyarak popüler bir kavram haline gelmiştir (Goleman, 1995). Öyle ki küresel iş liderlerinin sahip olması gereken üç temel zekâ tipinden ikisinin duygusal ve kültürel zekâ olduğu; dolayısıyla bu iki zekâ türünün mantıksal ve rasyonel düşünme açısından bilişsel zekâ (IQ) kadar önemli olduğu ileri sürülmüştür (Sauer, 2008).

Modern sinıflar farklı kültürlerden gelen öğrencileri bir araya getirmektedir (İnan, 2017). Bireylerin yaşadıkları toplumdaki yaygın kültürü ve aynı zamanda azınlık niteliğinde olan kültürleri tanımalarını sağlayacak bilgi, beceri ve yaklaşımlara sahip olmaları ancak kültürel çeşitliliği önemseyen bir eğitim sisteminin varlığında mümkün olmaktadır (Molina, 2013). Özellikle öğretmenler çok kültürlü eğitim kavramının ilkeleri arasında yer alan hoşgörü, eşitlik, kültürel farklılıklara saygı, uzlaşma vb. kavramları aşılamada ve tüm öğrencilere eşit başarı fırsatı sağlamada önemli bir rol oynamaktadır (Yüksel ve Ereş, 2018). Bu bağlamda duygusal zekâ, duyguları tanıma ve düzenleme yeteneği olarak tanımlanırken (Dhani ve Sharma, 2016); kültürel zekâ kişinin kendi kültürel bağlamından farklı olarak yeni kültürel ortamlara başarılı bir şekilde uyum sağlama yeteneği olarak belirlenmiştir (Jafari, 2013). Duygusal ve kültürel zekâ kişinin diş çevre ile iletişiminde, olayları anlamlandırmasında ve tepkilerini düzenlemesinde oldukça önemli iki unsur olup, bireyin sosyal ve iş hayatındaki ilişkilerini başarı ile sürdürmesinin destekçileridir

Çalışmanın bir diğer önemli değişkeni olan sosyal sermaye kavramı ise sosyal ağların değeri ile ilgilidir. Benzer insanları birbirine bağlamakta ve karşılıklılık normlarıyla farklı insanlar arasında köprü kurmaktadır (Claridge, 2004). Öğretmenlerin öğrencileriyle ve meslektaşlarıyla kurduğu etkili iletişim, okul içerisinde oluşturulan güven ortamı, iş birliği, öğretmenlerin iş tatminine ve okula bağlılığına katkı sağlamaktadır. 1960'larda James S. Coleman, gençlik (lise) kültürü ve ABD eğitimindeki fırsat eşitsizlikleri ile ilgili araştırmaları ve yenilikçi analizleriyle güçlü bir ün salmıştır. Coleman (1988) öğrencilerin okul performanslarının beklenenden daha iyi olabileceğini açılayacak unsurların aile ilişkileri ve topluluk ilişkileri olduğunu vurgulamıştır (Gudmundsson ve Mikiewicz, 2012). Fakhrerad'ın (2018) çalışmasında sosyal sermaye ve kültürel zekâ, pozitif yönde, anlamlı ve doğrudan bir ilişkiye sahiptir. Aküzüm ve Tan'ın (2014) çalışması, sosyal sermaye, iş tatmini ve örgütsel bağlılık arasında anlamlı bir ilişki olduğunu ortaya koymaktadır.

Bazı öğretmenler günlük stres yükünün üstesinden gelmeyi başarabilirken diğerleri bunu başaramamaktadır. Bu durumda tüm öğretmenlerin neden stresli durumdan eşit derecede etkilenmediği sorusu ortaya çıkmaktadır. Bunun birkaç nedeni olabilmektedir ancak en önemli sebeplerinden biri öğretmenler arasındaki duygusal ve kültürel zekâ farklılık düzeyidir (Kuchy ve Thilagavathy, 2017). Bu tür durumlarda başarılı olmak için öğretmenler açısından yapılması gerekenler, duygularını denetleme, empati kurma, başkalarının duygularını anlama, farklı bir ortama, kültüre kolaylıkla uyum sağlama ve farklı kültürel geçmişe sahip kişilerle kolayca iletişime geçme becerisine sahip olma şeklinde sıralanmaktadır.

Bir eğitim ortamında kültürel farklılıkların çatışmaya sebep olmadan bir uyum içerisinde 
yönetilmesi öğretmenin mesleki yeterliklerinin bir parçasıdır. Bu bağlamda öğretmenlerin kültürler arası iletişim becerileri yüksek bireyler olmaları gerekmektedir. Kültürel olarak yetkin öğretmenler, eğitim verdikleri öğrencilerin ve ailelerinin değerlerine, inançlarına, geleneklerine sayg1 duymaktadır (İnan, 2017). Kültürel zekânın dört boyutu, öğretmenler için gerekli olan kültürel yeterlilik ve etkinlik unsurlarını da içermektedir. Bilişsel kültürel zekâ, kültürel değerleri, normları, öğrencilerin kültür sistemlerini bilme; motivasyonel kültürel zekâ, öğrencilerle kültürlerarası etkileşimlerinde gerçekten başarılı olma isteği; davranışsal kültürel zekâ, kendi kültürel davranışlarını ve normlarını öğrencilere dayatmadan uygun şekilde davranma kapasitesidir. Öğretmenlerin metabilişsel kültürel zekâsı, öğrencilerin kültürel yapıları hakkında farkındalığa sahip olmasıdır (Molina, 2013).

Öğretmenler, öğrencilerini farklı kültürlerin iç içe bulunduğu küresel bir dünyada yaşama ve çalışma hayatına hazırlamaktadır. Öğretmenlerin, öğrencilerini daha iyi anlayabilmeleri ve onlara daha etkili bir şekilde eğitim verebilmeleri için kültürel zekâlarını etkin şekilde kullanmaları gerekmektedir (Petrovıc, 2011). Bu bağlamda duygusal ve kültürel zekâsı yüksek öğretmenler hem okul içi ve dışı çevreyle iletişime hem de öğrencilerine verilen eğitim kalitesine katkı sağlayabilmektedir. Aynı zamanda, duygusal ve kültürel zekânın, öğretmenlerin iş tatminleri ve örgüte bağl1lıkları üzerinde olumlu etkileri olduğu ileri sürülmektedir. Çalışmalar duygusal ve kültürel zekânın iş tatmini ve örgütsel bağlılık ile pozitif ilişkili olduğunu ortaya koymuştur (Eskandarpur vd., 2013; Siddique vd., 2014; Tabassum, 2015). Türkiye'de ilgili alanyazında bu ilişkiler arasında anlamlı ve pozitif yönlü ilişkiler olduğu kanıtlanmıştır (Korkmaz, 2018; Duru, 2020; Güvercin, 2020). Gürbüz ve Yüksel'in (2008) çalışmasında ise duygusal zekâ ve iş tatmini arasında anlamlı bir ilişkisi tespit edilememiştir. Fakat bu ilişkilerin öğretmenler açısından sorgulandığ 1 araştırmalar halen kısıtlıdır (Doğan, 2009; Kabar, 2017).

Sosyal sermayenin alt boyutları olan öğretmenlerin öğrencileriyle, meslektaşlarıyla ve idarecileriyle kurduğu etkili iletişim, okul içerisinde oluşturulan güven ortamı ve işbirliği, öğretmenlerin iş tatminini ve okuluna karşı bağlılığını artıracak önemli unsurlardır. Okulların sahip olduğu sosyal sermayeye ilişkin öğretmen görüşleri, okulun sosyal sermayesini oluşturan unsurların neler olduğunu belirlemeye yönelik veriler sağlayabilir. Ayrıca okulun sosyal sermayesi üzerinden okulun gelişimi için hangi sosyal sermaye unsurlarının güçlendirilebileceğine dair yol gösterici bilgilere olanak sağlanabilir (Köybaşı vd., 2017). Bu sebeple çalışmada öğretmenlerin duygusal ve kültürel zekâ düzeyinin iş doyumu ve örgütsel bağlılığa etkisi, sosyal sermaye aracılığıyla bu etkinin farklılık gösterip göstermediği incelenmek istenmiştir. Ulusal alanyazında sosyal sermayenin duygusal zekâ, kültürel zeka, iş tatmini ve örgütsel bağlılık ile ilişkisini gösteren araştırmalar mevcuttur (Aküzüm ve Tan, 2014; Çelik, 2014; Özmen vd., 2014; Özan, Özdemir ve Yaraş, 2017). Duygusal ve kültürel zekânın iş tatmini ve örgütsel bağlılık ilişkisinde sosyal sermayenin aracılık rolünü sorgulayan bir çalışmaya rastlanılmamıştır. Bu bağlamda topluma yön veren eğitim faaliyetlerinin etkili bir şekilde sürdürülmesinde önemli rol oynayan öğretmenlerin duygusal ve kültürel zeka yeterliliklerinin belirlenmesi, duygusal ve kültürel zeka ile sosyal sermaye, iş tatmini ve örgütsel bağlılık arasındaki ilişkinin ortaya konması gerekmektedir.

Yukarıdaki açıklamalar doğrultusunda bu araştırmanın temel amacı, öğretmenlerin duygusal ve kültürel zekâ düzeyinin iş tatmini ve örgütsel bağlllığa etkisini incelemek ve sosyal sermaye aracılığıyla bu etkinin farklılık gösterip göstermediğini ortaya koymaktır. Araştırma amacı çerçevesinde elde edilen bulguların alanyazına katkısı, duygusal ve kültürel zekâ boyutlarının sosyal sermaye ile bir arada etkilerinin sorgulanarak ulusal ve uluslararası alanyazında yer alan 
mevcut çalışmalardan daha bütüncül bir bakış açısıyla kapsamlı bir model oluşturmasıdır.

\section{YÖNTEM}

Bu bölümde hipotezlerin belirlenmesi, açıklayıcı araştırma yöntemi kullanılarak yapılandırılan araştırma modeli, araştırma örneklemi, veri toplama yöntemi, araştırmada kullanılan ölçekler ve verilerin analizi ile ilgili bilgilere yer verilmiştir.

\section{Hipotezlerin Belirlenmesi ve Araştırma Modeli}

\section{Doğrudan İlişkiler}

Duygusal zekâ ile iş tatmini ve örgütsel bağlılık ilişkisi: Duygusal zekâ yaratıcılık duygusunun artmasına katkıda bulunmakta, yenilikçi düşünceyi teşvik etmekte, stresi azaltmakta ve ilişkileri geliştirmektedir. Bireyin isteklerini zihinsel, duygusal ve manevi düzeyde yerine getirmesini ve etkili bir şekilde başkalarıyla ilişki kurmasını sağlamaktadır. Duygusal zekâsı yüksek öğretmenler, ekip çalışması, katılımcı karar verme, göreve adanma, sorumlu ve üretken olma, anlaşmazlıkların ve ihtilafların azaltılması gibi konularda örgüte katkı sağlamaktadır. Yapılan çalışmalar da duygusal zekâsı yüksek öğretmenlerin düşük duygusal zekâya sahip öğretmenlere göre daha fazla örgütsel bağlılığa sahip olduğunu göstermiştir (Anari, 2012; Atmaja, Hardhienata ve Sunaryo, 2015). Nikkheslat'ın (2012) çalışmasının bulguları duygusal zekânın örgütsel bağlılık ile ilişkiye sahip olduğunu ancak bu ilişkinin sadece iş tatmini ile gösterildiğini ortaya koymuştur. İş tatmininin duygusal zekâ ve örgütsel bağlılık arasında aracı etkiye sahip olduğu tespit edilmiştir. Bahsedilen çalışmalara dayanarak duygusal zekânın örgütsel bağlılık üzerindeki etkisini ortaya koymak amacıyla araştırmanın ilk hipotezi geliştirilmiştir.

Hipotez 1: Duygusal zekânın örgütsel bağlılık üzerinde anlamlı ve pozitif etkisi vardır.

Öğretmenlerin karşılaştığı sorunlar karşısında sakin, endişeli, mutsuz ya da gergin olması çalışma hayatını doğrudan etkilemektedir. Duygularını denetleyebilen, özellikle olumsuz duygularla baş edebilen, empati kurabilen, başkalarının duygularını anlayabilen öğretmenlerin iş tatmininin daha yüksek olacağı düşünülmektedir. Bu bilgiler 1şığında yapılan çalışmalarda da duygusal zekâ ve iş tatmininin pozitif ilişkili olduğu görülmüştür (Akomolafe ve Ogunmakin, 2014; Mondol ve Soho, 2017; Narasimhan, 2018). Bundan dolayı duygusal zekâ düzeyi yüksek olan öğretmenlerin iş tatminlerinin daha fazla, duygusal zekâ potansiyelini yeterince kullanamayan öğretmenlerin iş tatminlerinin düşük olması beklenir. Benzer şekilde akademisyenlerin duygusal zekâsı ve iş tatminini ele alan çalışmalarda yüksek duygusal zekâya sahip akademisyenlerin yüksek memnuniyet düzeyine sahip olduğu görülmüştür (Ahmed, 2015; Tabassum, 2015). Bilimsel araştırmalar kapsamında duygusal zekânın iş tatmini üzerindeki etkisini ortaya koymak amacıyla araştırmanın ikinci hipotezi oluşturulmuştur.

Hipotez 2: Duygusal zekânın iş tatmini üzerinde anlamlı ve pozitif etkisi vardır.

Kültürel zekâ ile iş tatmini ve örgütsel bağlılık ilişkisi: Kültürel zekâ, farklı kültürlerden insanlar ile etkileşimlerde bulunmak, bu tür etkileşimlerde ortaya çıkabilecek sorunları çözmek gibi bireylerin sahip oldukları yetenekleri temsil etmektedir. Kültürel zekâ potansiyelini etkin kullanabilen öğretmenler, farklı kültürel çevrelere uyum sağlayıp etkin ve verimli bir şekilde çalışabilmektedir. Kültürel zekâ düzeyi aynı zamanda öğretmenlerin çalıştıkları okulun özelliklerini, okulun bakış açısını ne ölçüde içselleştirdiğini ve kendine uyarladığını da göstermektedir. Yapılan çalışmalar bu görüşü destekler niteliktedir. (Azarvand, Feizi ve Alipour, 
2013; Eskandarpur vd., 2013) Bahsedilen bilgiler 1şığında kültürel zekanın örgütsel bağlılık üzerindeki etkisini ortaya koymak amacıyla araştırmanın üçüncü hipotezi geliştirilmiştir.

Hipotez 3:Kültürel zekânın örgütsel bağlllık üzerinde anlamlı ve pozitif etkisi vardır.

Öğretmenlerin, yaşadıkları toplumdaki yaygın kültürü ve aynı zamanda azınlık niteliğinde olan kültürleri tanımaları, bu kültürlerle etkin bir şekilde iletişim kurmalarını sağlayacak bilgi, beceri ve yaklaşımlara sahip olmaları iş tatminleri üzerinde oldukça etkilidir. Kültürel zekâsı yüksek öğretmenlerin düşük kültürel zekâya sahip öğretmenlere göre iş tatmininin daha yüksek olduğu yapılan çalışmalarla desteklenmektedir (Şahin, 2011; Srinavas ve Patric, 2018). Diao ve Park'ın (2012) çalışmasında kültürel zekanın motivasyon ve davranışsal boyutu ile iş tatmini arasında anlamlı ve pozitif ilişki bulunmuştur. Mevcut çalışmalara dayanarak kültürel zekânın iş tatmini üzerindeki etkisini ortaya koymak amacıyla araştırmanın dördüncü hipotezi geliştirilmiştir.

Hipotez 4:Kültürel zekânın iş tatmini üzerinde anlamlı ve pozitif etkisi vardır.

\section{Dolaylı İlişkiler}

Sosyal sermayenin duygusal zekâ ile iş tatmini ilişkisinde aracılık rolü: Sosyal sermayenin bireylere sağladığı faydalar, ağ yapısı ve ağın özellikleri, duygusal zekâ ve iş tatmini arasındaki ilişkide önemli bir etkiye sahiptir. Kurum içerisinde çalışanlar meslektaşları ve idarecileri ile güvenilir ilişkilere ve sıkı bağlara sahip ise bu bağlar çalışanların iş tatminini olumlu bir şekilde etkileyecektir. Sosyal sermaye ile iş tatmini arasında pozitif ilişki bulunmuştur (Rezaee ve Nabeiei, 2016). Duygusal zekâ ve sosyal sermaye arasında da anlamlı ve pozitif ilişki bulunduğu görülmüştür (Çelik, 2014; Najafi ve Sorgolzaei, 2014). Isfahan Üniversitesi'nde duygusal zekâ grubu eğitiminin beşeri ve sosyal sermaye üzerindeki etkisi" adlı çalışmada ise duygusal zekâ eğitiminin beşeri sermaye üzerinde etkisi olmuştur ancak duygusal zekâ eğitiminin sosyal sermaye üzerinde hiçbir etkisi olmamıştır (Charsoughi, Abedi ve Nilforoushan, 2015)

Sosyal sermayenin duygusal zeka ve örgütsel bağlılık ilişkisinde aracılık rolü: Duygusal zeka potansiyelini iyi kullanabilen öğretmenler, empati kurmak, ılımlı ve anlayışlı olmak, başkalarının duygularını anlamak, kendi duygularının farkına varmak ve duygularını kontrol etmek gibi sahip oldukları yetkinliklerle okulda pozitif bir okul kültürü ve iklimi oluşmasına katkı sağlamaktadır (Şahin, Aydoğdu ve Yoldaş, 2011). Okula ve okulun değerlerine bağl1lık, okulun amaç ve hedeflerini gerçekleştirme arzusu gibi kavramlar, okul personelini bir arada tutan bağın gücünü göstermektedir. Bu kavramları içselleştiren öğretmenler, idarecileri tarafından yaptıkları işin takdir edilmesini isterler, bu takdiri gördüklerinde okulun çalışanı olmaktan gurur duyarlar. Yapılan çalışmalar da sosyal sermayenin örgütsel bağlılık ile anlamlı ve pozitif bir ilişkiye sahip olduğunu desteklemektedir (Sayadi ve Hayati, 2014; Emhan, Tongur ve Türkoğlu, 2016). Bu ilişki öğretmenlerin okula bağlılıklarının artmasına katkı sağlamaktadır. Bu bağlamda insan ilişkileri, güven ortamı, grup dayanışması, duygusal zekâ ve örgütsel bağlılık ilişkisinde önemli bir aracı etken olarak ortaya çıkmaktadır.

Sosyal sermayenin kültürel zekâ ve iş tatmini ilişkisinde aracılık rolü: Öğretmenlerin farklı kültürel kimliklere sahip öğrencilerin kültürel normlarını öğrenmesi ve her öğrenciyi benzersiz kılan grup içi farklılıkları anlama becerisi, farklı kültürlerin bir arada olduğu sınıflarda ortaya çıkabilecek sorunları önlemekte ve etkili bir eğitim - öğretim ortamı için zemin hazırlamaktadır. Yapılan çalışmalar kültürel zekâ ile sosyal sermaye arasında anlamlı ve pozitif bir ilişki olduğunu göstermiştir.( Jafari, 2013; Fakhrerad, 2018). Sosyal sermaye, bir sosyal sistemdeki bireyler 
arasındaki ilişkisel bağların bir özelliğidir. Sosyal sermayenin önemli bileşenleri olan güven, işbirliği, hedef odaklı bir eğitim sistemi oluşturma, kültürel zekâ ile iş tatmini ilişkisini artırmaktadır. Öğretmenler açısından sosyal sermaye kavramı, öğretme ve öğrenmeyi geliştirmek için gruplar halinde çalışmaya olanak sağlayan meslektaş dayanışması ve işbirliği gibi bir dizi sosyal etkileşim varlığını içermektedir. Sosyal sermaye ile ilgili bu faktörler bireyin iş tatmininin artmasına katkı sağlamaktadır. Alan yazında bulunan çalışmaların sonuçları, sosyal sermayenin iş tatmininin önemli bir yordayıcısı olduğunu göstermektedir (Rostami vd., 2013; Özmen vd., 2014).

Sosyal sermayenin kültürel zekâ ve örgütsel bağlılık ilişkisinde aracılık rolü: Kültürel zekâ, karmaşık ve sürekli değişen durumlarda insanların inançlarını, değerlerini, tutumlarını ve davranışlarını etkili bir şekilde anlama ve bunlara yanıt verme yeteneğidir. Çalışma ortamında ortaya çıkabilecek iletişim sorunlarını ve yanlış anlaşılmaları en aza indirmektedir. Kültürel zekâ, eğitim ortamında güven duygusunun oluşmasına katkı sağlamaktadır. Güven, daha iyi karar verme süreçlerine götüren, verimliliği sağlayan bir katalizör olarak düşünülebilir. Tartışmalı kararların sayısını azaltır. Tartışmalar yerine öğretim hedeflerine daha fazla zaman harcanmasına katkıda bulunur. Sıkı ve sıkıcı denetimler yerine örtük, içselleştirilmiş yükümlülükler yaratır. Yüksek güven düzeyine sahip okullar, öğretmenlerini daha fazla bağlllık konusunda harekete geçirir. Alan yazında sosyal sermaye ve örgütsel bağlılık değişkenleri arasında pozitif yönde bir ilişkinin olduğu tespit edilmiştir. (Erbaş ve Sanioğlu, 2016).

Duygusal ve kültürel zekâ, modelin bağımsız değişkenleri; iş tatmini ve örgütsel bağlılık bağımlı değişkenleridir. Ayrıca değişkenler arası ilişkilerde sosyal sermayenin aracılık rolü sorgulanmıştır. Adı geçen değişkenler ile yapılan bu çalışmada ulusal ve uluslararası literatürde yer alan mevcut çalışmalardan daha bütüncül bir bakış açısıyla daha kapsamlı bir model oluşturmak için dolaylı etkiyi ortaya koyan hipotez geliştirilmiştir.

Dolaylı etki: Duygusal zekâ ve kültürel zekâ ile iş tatmini ve örgütsel bağlllık ilişkisinde sosyal sermayenin aracı etkisi bulunmaktadır. Bu doğrultuda çalışmanın modeli aşağıda sembolize edilmiştir.

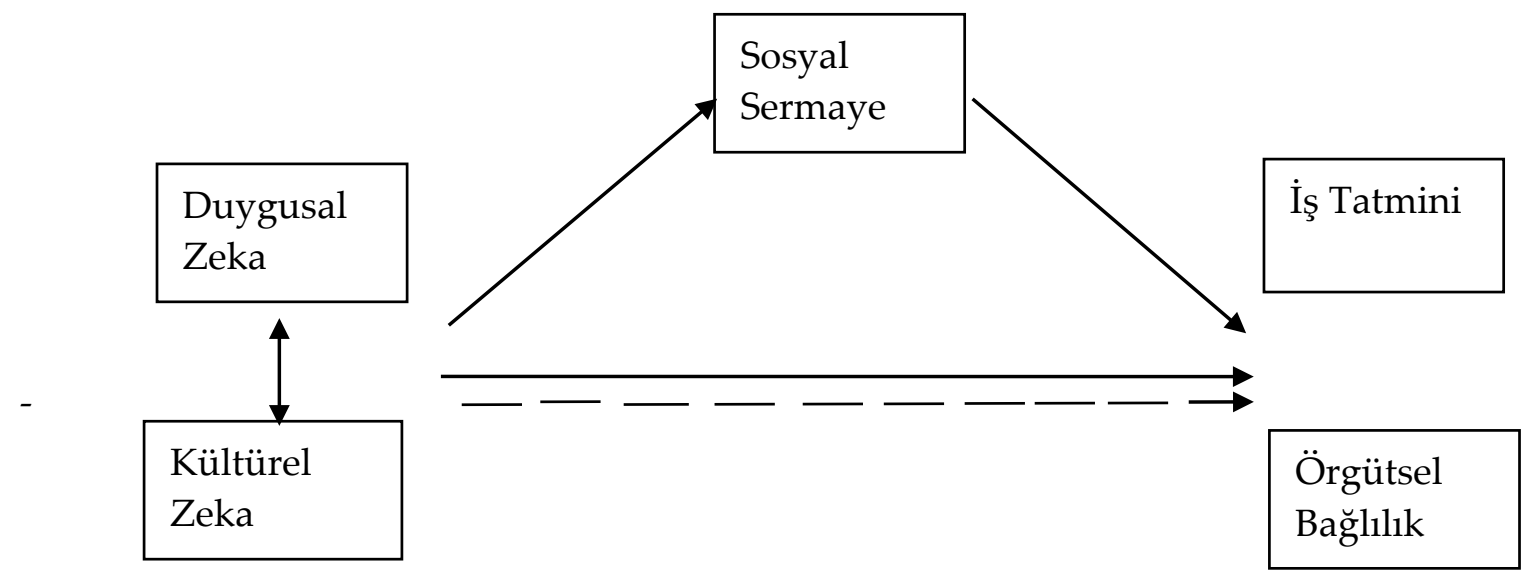

Şekil 1. Araştırmanın Modeli

Araştırma yöntemi nicel araştırma yöntemlerinden açıklayıcı araştırma yöntemidir. Açılayıcı araştırma değişkenler arasında nedensellik ilişkisini açıklamayı amaçlayan araştırmalardır (Gürbüz ve Şahin, 2016).

$\mathrm{Bu}$ araştırmada da kültürel ve duygusal zekâ ile iş tatmini ve örgütsel bağlllık ilişkisinde sosyal sermayenin aracı etkisi sorgulanmaktadır. 


\section{Araştırma Örneklemi ve Veri Toplama Yöntemi}

Duygusal zekâ ve kültürel zekâ, sosyal sermaye, iş tatmini ve örgütsel bağlılık ilişkilerinin incelendiği bu araştırmanın evreni, 2018- 2019 akademik yılında İstanbul İlinde resmi ilkokul ve ortaokullarda görev yapan 64.673 öğretmenden oluşmaktadır. 2018-2019 akademik yılında İstanbul İli genelinde resmi ilkokul ve ortaokullarda görev yapan 64.673 öğretmen bulunmaktadır (Meb, 2019). Araştırmanın örneklemini ise 642 öğretmen oluşturmaktadır. Araştırma örneklemi, \%95 güven aralığında evreni temsil etme yeteneğine sahiptir. Araştırmacılar genellikle \%5'lik bir belirlilik düzeyinde çalışırlar. Bunun anlamı şudur: eğer örnek kütleniz 100 kere seçilmiş olsa, bunlardan en az 95 tanesi evrenin özelliklerini temsil edecek güce sahiptir (Coşkun vd., 2015, s.137). Örnekleme metodu olarak kartopu örnekleme metodu kullanılmıştır. Kartopu örnekleme, araştırmaya uygun katılımcıların belirlenmesiyle bu katılımcılardan elde edilen bilgi ve tavsiyelerden hareketle yeni katılımcıların araştırmaya dahil edilmesiyle gerçekleştirilir (Gürbüz ve Şahin, 2016). Toplamda 700 kişiye anket uygulanmıştır. Ancak eksik ve uygun doldurulmamış 58 anket, örneklem dışına alınmış ve 642 öğretmenin verileri analiz edilmiştir.

Tablo 1: Demografik Bilgiler

\begin{tabular}{|c|c|c|}
\hline Branş & $\mathbf{n}$ & $\%$ \\
\hline Sinif & 147 & 22.9 \\
\hline Sosyal alanlar & 182 & 28.3 \\
\hline Sayısal alanlar & 155 & 24.1 \\
\hline Dil & 90 & 14 \\
\hline Diğer & 68 & 10.6 \\
\hline Yaş & $\mathrm{n}$ & $\%$ \\
\hline $21-25$ yaş & 29 & 4.5 \\
\hline $26-30$ yaş & 234 & 36.4 \\
\hline $31-35$ yaş & 265 & 41.3 \\
\hline 36 ve üstü yaş & 114 & 17.8 \\
\hline Cinsiyet & $\mathrm{n}$ & $\%$ \\
\hline Kadın & 359 & 55.9 \\
\hline Erkek & 283 & 44.1 \\
\hline Eğitim durumu & $\mathrm{n}$ & $\%$ \\
\hline Üniversite & 616 & 96 \\
\hline Yüksek Lisans & 24 & 3.7 \\
\hline Doktora & 2 & 0.3 \\
\hline Hizmet süresi & $\mathrm{n}$ & $\%$ \\
\hline 1 yıldan az & 24 & 3.7 \\
\hline $1-5$ yil & 236 & 36.8 \\
\hline 6-10 y1l & 238 & 37.1 \\
\hline $11-15$ yıl & 103 & 16 \\
\hline 15 y1ldan fazla & 41 & 6.4 \\
\hline Bu okulda çalışma süresi & $\mathrm{n}$ & $\%$ \\
\hline 1yıldan az & 47 & 7.3 \\
\hline $1-5 \mathrm{yll}$ & 405 & 63.1 \\
\hline 6-10 yil & 173 & 26.9 \\
\hline $11-15$ y1l & 17 & 2.6 \\
\hline
\end{tabular}


Branşlar incelendiğinde diğer alanların kapsamını Beden Eğitimi, Görsel Sanatlar, Müzik, Rehberlik ve Psikolojik Danışmanlık branşları oluşturmaktadır. Ankete katılan öğretmenlerin ağırlıklı olarak 31-35 yaş $(\mathrm{n}=265)$ aralığında olduğu görülmektedir. $\mathrm{Bu}$ bulgu araştırma kapsamındaki öğretmenlerin oldukça genç olduğu sonucunu ortaya koymaktadır.

Araştırmaya katılan öğretmenlerin büyük oranda (616 kişi) lisans mezunu olduğu ve lisansüstü eğitime yeterince katılmadıkları görülmektedir. Öğretmenlerin \%26.9'u (n=173) 6-10 yıl arası hizmet süresine sahiptir. Eğitim sektöründeki öğretmenlerin yaş ortalaması genç grubu oluşturmasına rağmen öğretmenlik yılları ilerledikçe çalışma koşullarına alıştıkları ya da okul politikalarına daha rahat uyum sağlayabildikleri görülmektedir. Bu durumda öğretmenlerin mesleklerinde tecrübeli oldukları söylenebilmektedir. Ankete katılanların büyük çoğunluğunun (n=405) 1-5 yıl arası bulunduğu okulda çalışma süresine sahip olduğu tespit edilmiştir. Öğretmenlerin soruları doğru bir şekilde cevaplayabilmesi için sahip oldukları mesleki ve görev yaptıkları kurum ile ilgili edindikleri tecrübe bakımından bu oran oldukça yeterli gözükmektedir.

\section{Veri Toplama Araçları}

Aşağıda araştırmada kullanılan veri toplama araçları ile ilgili bilgiler yer almaktadır.

Duygusal Zekâ Ölçeği: Wong ve Law tarafından geliştirilen İşler ve Atilla'nın (2013) çalışmasında Türkçe formu kullanılan 16 ifadeden oluşan duygusal zekâ ölçeği kullanılmıştır. İşler ve Atilla'nın çalışmasında ölçeğin Cronbach Alfa değeri 0.846dır. Alt boyutları, kendi duygularını değerlendirme, başkalarının duygularını değerlendirme, duyguların kullanılması, duyguların düzenlenmesidir.

Kültürel Zeka Ölçeği: Kültürel zeka ölçeği, Ang, Van Dyne, Koh,Yee Ng, Templer,Tay ve Chandrasekar (2007) tarafından geliştirilmiş, Şahin, Gürbüz, Köksal ve Ercan (2012) tarafından Türkçeye uyarlanmıştır. Ölçeğin Türkçe formu, Ulusoy'un (2017) yüksek lisans tezinden alıntıdır. Ulusoy'un tezinde ölçeğin, Cronbach Alfa değeri 0.75 olarak bulunmuştur. 20 ifadelik bir ölçektir. Ölçek, üstbilişsel, bilişsel, motivasyonel ve davranışsal olmak üzere 4 alt boyuttan oluşmaktadır.

Sosyal Sermaye Ölçeği: Sosyal sermaye algısı ölçeği Günkör (2016) tarafından geliştirilmiştir. Günkör 'ün doktora tezinde ölçeğin Cronbach Alfa değeri 0.929'dur. 21 ifade bulunmaktadır. Ölçek, sosyal normlar, sosyal ağlar ve güven olmak üzere 3 alt boyuttan oluşmaktadır.

İş Tatmini Ölçeği: Brayfield ve Rothe (1951) tarafından oluşturulmuş, Yoon ve Thye (2002) tarafından geliştirilmiştir. Ölçeğin Türkçe formu, Kuşluvan ve Kuşluvan'ın (2005) çalışmasından alıntıdır. Ölçeğin Kuşluvan ve Kuşluvan'ın çalışmasında Cronbach Alfa değeri 0.84 'tür. 5 ifadeden oluşmaktadır.

Örgütsel Bağlılık Ölçeği: Allen ve Meyer (1993) tarafından geliştirilmiştir. Ölçek, Gürkan (2006) tarafından Türkçeye çevrilmiştir. Gürkan'ın yüksek lisans tezinde ölçeğin Cronbach Alfa değeri 0.745 tir. 18 ifadeden oluşmaktadır. Ölçeğin alt boyutları, duygusal bağlılık, devam bağlılı̆̆ ve normatif bağlliktır.

Araştırmada uygulanan anketlerin cevaplandırılmasında 5'li Likert tutum ölçeği kullanılmıştır. Ankette yer alan ifadelerin değerlendirme seçenekleri; (1) Kesinlikle katılmıyorum, Katılmıyorum, (3) Kararsızım, (4) katılıyorum, (5) Kesinlikle katılıyorum şeklindedir. 


\section{Verilerin Analizi}

Çalışmanın tüm alt boyutlarının yer aldığı güvenirlik analizinde Cronbach Alfa katsayısı 0,940 olarak tespit edilmiştir. Ayrıca çalışmada yer alan tüm alt boyutların güvenirlik analiz değerleri 0,875 ile 0, 976 arasında dağılım göstermiştir.

Tablo 2: Güvenirlik ve Geçerlilik Tablosu

\begin{tabular}{lllll}
\hline Faktör İsimleri & Alpha & rho_A & CR & AVE \\
\hline Başkalarının duygularını değerlendirme & 0,892 & 0,893 & 0,925 & 0,756 \\
\hline Duyguların düzenlenmesi & 0,918 & 0,920 & 0,942 & 0,802 \\
\hline Kendi duygularını değerlendirme & 0,920 & 0,920 & 0,944 & 0,807 \\
\hline Duyguların kullanılması & 0,918 & 0,938 & 0,942 & 0,804 \\
\hline İş tatmini & 0,902 & 0,903 & 0,932 & 0,773 \\
\hline Üst bilişsel kültürel zekâ & 0,967 & 0,969 & 0,976 & 0,910 \\
\hline Bilişsel kültürel zekâ & 0,899 & 0,917 & 0,924 & 0,709 \\
\hline Motivasyonel kültürel zekâ & 0,930 & 0,930 & 0,947 & 0,781 \\
\hline Davranışsal kültürel zekâ & 0,976 & 0,976 & 0,981 & 0,913 \\
\hline Sosyal normlar & 0,933 & 0,940 & 0,946 & 0,718 \\
\hline Sosyal ağlar & 0,921 & 0,924 & 0,938 & 0,684 \\
\hline Güven & 0,922 & 0,924 & 0,938 & 0,685 \\
\hline Duygusal bağlılık & 0,875 & 0,886 & 0,923 & 0,799 \\
\hline Devam bağlılığ1 & 0,879 & 0,879 & 0,926 & 0,806 \\
\hline Normatif bağlılık & 0,908 & 0,913 & 0,929 & 0,686 \\
\hline
\end{tabular}


Tablo 3: Yol Modeli ve Beta Katsayıları Analizi

\begin{tabular}{|c|c|c|c|c|c|c|c|c|c|c|c|c|c|c|c|}
\hline Faktör İsimleri & 1 & 2 & 3 & 4 & 5 & 6 & 7 & 8 & 9 & 10 & 11 & 12 & 13 & 14 & 15 \\
\hline $\begin{array}{l}\text { Başkalarının duygularını } \\
\text { değerlendirme (1) }\end{array}$ & & & & & 0,033 & & & & & 0,143 & 0,048 & 0,039 & 0,061 & 0,046 & 0,062 \\
\hline $\begin{array}{l}\text { Duyguların düzenlenmesi } \\
\text { (2) }\end{array}$ & & & & & 0,062 & & & & & 0,085 & 0,231 & 0,225 & 0,138 & 0,150 & 0,125 \\
\hline $\begin{array}{l}\text { Kendi duygularını } \\
\text { değerlendirme (3) }\end{array}$ & & & & & 0,041 & & & & & 0,156 & 0,051 & 0,095 & 0,082 & 0,064 & 0,074 \\
\hline $\begin{array}{l}\text { Duyguların kullanılması } \\
\text { (4) }\end{array}$ & & & & & 0,105 & & & & & $-0,041$ & $-0,017$ & 0,002 & $-0,014$ & $-0,010$ & $-0,017$ \\
\hline \multicolumn{16}{|l|}{ İş tatmini(5) } \\
\hline $\begin{array}{l}\text { Üst bilişsel kültürel zekâ } \\
\text { (6) }\end{array}$ & & & & & 0,040 & & & & & 0,079 & 0,017 & 0,026 & 0,033 & 0,023 & 0,032 \\
\hline Bilişsel kültürel zekâ (7) & & & & & $-0,029$ & & & & & $-0,066$ & $-0,033$ & 0,009 & $-0,022$ & $-0,017$ & $-0,028$ \\
\hline $\begin{array}{l}\text { Motivasyonel kültürel } \\
\text { zekâ (8) }\end{array}$ & & & & & $-0,029$ & & & & & 0,144 & 0,177 & 0,204 & 0,137 & 0,134 & 0,123 \\
\hline $\begin{array}{l}\text { Davranışsal kültürrel zekâ } \\
\text { (9) }\end{array}$ & & & & & 0,075 & & & & & $-0,032$ & $-0,021$ & $-0,098$ & $-0,043$ & $-0,038$ & $-0,029$ \\
\hline Sosyal normlar (10) & & & & & 0,222 & & & & & & & & 0,277 & 0,135 & 0,291 \\
\hline Sosyal ağlar (11) & & & & & 0,247 & & & & & & & & 0,195 & 0,331 & 0,301 \\
\hline Güven (12) & & & & & 0,133 & & & & & & & & 0,307 & 0,277 & 0,137 \\
\hline \multicolumn{16}{|l|}{ Duygusal bağlılık (13) } \\
\hline \multicolumn{16}{|l|}{ Devamlı bağlılık (14) } \\
\hline Normatif bağlılık (15) & & & & & & & & & & & & & & & \\
\hline
\end{tabular}


Yol Modeli ve Beta Katsayıları analizinde Path Analizi yönteminden yararlanılmıştır. Bilindiği üzere bir PLS modeli iki aşamada analiz edilir ve yorumlanır: birincisi, ölçüm modelinin güvenilirliğinin ve geçerliliğinin değerlendirilmesi; ikincisi ise yapısal modelin değerlendirilmesidir. Bu sıralama, yapılar arasındaki ilişkilerle ilgili sonuçlar çıkarmaya çalışmadan önce yapıların ölçütlerinin geçerli ve güvenilir olmasını sağlar (Barclay, Higgins ve Thompson, 1995). Ampirik çalışmanın bağımsız değişkenleri olan duygusal ve kültürel zekânın diğer değişkenler üzerindeki etkisi tablo 2'de görülmektedir. Duygusal ve kültürel zekâ, araştırma modelindeki saf bağımsız değişkenler olduğu için tablo üzerinde Beta değerleri bulunmamaktadır. Modelde yer alan sosyal sermaye kavramı aracı değişken rolündedir. Bununla birlikte örgütsel bağlılık ve iş tatmini, çalışmanın saf bağımlı değişkenleridir. Analizler kapsamında keşifsel faktör analizini takiben sırasıyla güvenirlik, doğrulayıcı faktör analizi, korelasyon ve yol analizi gerçekleştirilmiştir

\section{BULGULAR}

Yukarıda verilerin analizi kısmında tablo 3'de verilen analiz sonuçları incelendiğinde iş tatmini bağımlı değişkeni üzerinde duygusal ve kültürel zekânın herhangi bir etkisinin çıkmaması araştırmanın en dikkat çekici bulgularından birisidir. Ancak örgütsel bağlılı̆̆ın tüm alt boyutlarıyla (duygusal, devam ve normatif) iş doyumu üzerinde doğrudan ve pozitif yönde bir etkisi bulunduğu tespit edilmiştir. Özellikle 0,247'lik Beta katsayısı ile devamlılık boyutu iş doyumu ile yoğun bir sebep - sonuç ilişkisi içerisindedir. Duygusal ve kültürel zekânın sosyal sermaye üzerindeki etkilerine bakıldığında başkalarının duygularını değerlendirme boyutunun sosyal normlar üzerine; kendi duygularını değerlendirme boyutunun da sosyal normlar üzerine doğrudan bir etkisi olduğu anlaşılmıştır. Duyguların düzenlenmesi boyutu ise sosyal ağlar ve güven boyutlarını doğrudan etkilemektedir. Duygusal zekânın diğer bir boyutu olan duyguların kullanılması ise sosyal sermaye üzerinde herhangi bir anlamlı etkiye sahip değildir. Zekâ türlerinin sosyal sermaye ve alt boyutları üzerindeki etkilerine bakıldığında yol tablosunda yer alan beta değerleri ve bunların etkisi oldukça sınırlı kalmıştır. Diğer bir deyişle araştırmanın bağımsız değişkenleri kurumun sosyal sermayesi üzerindeki değişimlerin \%12.9 ile \%15.1'i arasında açıklayıcılık sağlamıştır. Bu değerler sosyal bilimler için gerekli olan açıklayıcılık sınırının üzerinde olmasına rağmen bu çalışmadaki araştırma modelinin gerekliliğini karşılamamaktadır. Tek alt boyutlu iş tatmini faktörüne bakıldığında araştırma modelinde beklendiği gibi çok kuvvetli bir açıklayıcılık oranı tespit edilmiştir. Araştırmanın bağımsız değişkenlerindeki 100 birimlik artış örgütte çalışanların iş doyumunu \%45.6 oranında arttırmaktadır. Diğer bir deyişle, iş tatminindeki değişimlerin \%45.6's1 kültürel, duygusal zekâ ile sosyal sermaye tarafından belirlenmektedir. Çalışmanın kilit bağımlı değişkeni örgütsel bağlılık incelendiğinde ise determinasyon katsayılarının \%46.6 ile \%53.5 arasında yer aldığı görülmektedir. Özellikle duygusal bağlılık alt faktörünün \%53.5 ile çok yüksek bir açıklayıcılık oranına sahip olduğu ve bağımsız değişkenler tarafından doğrudan etkilendiği kanıtlanmıştır. Duygusal ve kültürel zeka türlerinin duygusal bağlılık üzerine pozitif bir etkisinin bulunacağı öngörülen bu araştırmada literatür beklentisini karşılayacak sonuçlar elde edilmiştir. 
AJER - Academia Eğitim Araştırmaları Dergisi 2021, 6(2), 457-476

https://dergipark.org.tr/pub/egitim e-ISSN 2619-9351

Tablo 4: Aracı Değişken Analizleri

\begin{tabular}{|c|c|c|c|c|c|}
\hline & 1. adım & & & $\begin{array}{l}\text { 2. adım } \\
\text { (Tüm Model) }\end{array}$ & \\
\hline & $\begin{array}{l}\text { Orijinal } \\
\text { Örnek (ß) }\end{array}$ & & & $\begin{array}{l}\text { Orijinal } \\
\text { Örnek (ß) }\end{array}$ & \\
\hline DZ $->$ İT & -------- & & & -0.045 & \\
\hline $\mathrm{KZ}$-> İT & ------- & & & 0.039 & \\
\hline SS -> ÖB & 0.722 & & & ------ & \\
\hline $\mathrm{DZ}->\mathrm{SS}$ & 0.295 & & & 0.032 & \\
\hline $\mathrm{KZ} \rightarrow \mathrm{SS}$ & 0.141 & & & 0.046 & \\
\hline DZ -> ÖB & -0.022 & & & -0.005 & \\
\hline KZ -> ÖB & -0.026 & & & 0.046 & \\
\hline İT $>$ ÖB & 0.100 & & & ------ & \\
\hline \multirow{3}{*}{$\begin{array}{l}R \text { kare ve İndeks } \\
\text { Değerleri }\end{array}$} & İT & 0,456 & SS1 & 0,139 & 0,129 \\
\hline & SS3 & 0,161 & OB1 & OB2 $\quad 0,489$ & OB3 0,466 \\
\hline & SRMR: 0,057 & & NFI: 0,760 & CFI: 0,899 & GFI: 0,870 \\
\hline
\end{tabular}

DZ1: Başkalarının Duygularını Değerlendirme DZ2: Duyguların Düzenlenmesi DZ3: ÖZ Değerleme DZ4:Duyguların Kullanılması ITT: İş Tatmini, KZ1: Üst Bilişsel Kültürel Zeka KZ2: Bilişsel Kültürel Zeka KZ3: Motivasyonel Kültürel Zeka KZ4: Davranışsal Kültürel Zeka, SS1:Sosyal Normlar SS2:Sosyal Ağlar SS3: Güven, ÖB1:Duygusal Bağlılık ÖB2: Devamlılık Bă̆lılı̆̆ı ÖB3: Normatif Bă̆glılık

Tablo 4'de yer alan aracı değişken etkisi ile ilgili tüm analizlere bakıldığında, Tüm Beta değerleri ve Determinasyon Katsayıları iki sütun halinde verilmiştir. Analiz ikincil düzey olarak gerçekleştirilmiştir, önceki analizde çıkartılan sorular burada da yer almamıştır. Duygusal Zekâ ile Kültürel Zekânın Örgütsel Bağlılık Üzerindeki Etkilerini incelerken aracı değişken olarak kullanılan Sosyal Sermayenin herhangi bir aracılık etkisine rastlanmamıştır. Ancak Duygusal Zekâ ile Kültürel Zekânın Sosyal Sermaye üzerine etkileri incelediğinde birbirleri üzerinde aracılık etkisi bulunduğu tespit edilmiştir. Duygusal Zekâ ve Kültürel Zekâ birbirlerinden bağımsız olarak incelendiğinde Beta değerleri yüksek iken (0.295 ve 0.141); aracılık etkisi kontrol edilerek bakıldığında Beta değerlerinde ciddi bir azalma gözlemlenmiştir (0.032 ve 0.046). Aracı değişken etkisini analiz etmek için Baron ve Kenny'nin (1986) aracılık analizi yönteminden faydalanılmıştır. Bu görüşe göre, bağımsız değişkenle bağımlı değişken arasındaki ilişki, modele dâhil olan bir başka bağımsız değişken tarafından gölgeleniyorsa, aracı değişken etkisinden bahsedilmektedir (Koç, Kaya, Özbek ve Akkılıç, 2014). 
Yapılan analizler sonucunda araştırmada ileri sürülen hipotezler ile ilgili elde edilen bulguların özeti aşağıdaki Tablo 5 'de verilmiştir.

Tablo 5: Hipotez Sonuç Tablosu

\begin{tabular}{|c|c|}
\hline HİPOTEZLER & DURUMU \\
\hline $\begin{array}{l}\text { H1: Duygusal zekânın örgütsel bağlllık } \\
\text { üzerinde anlamlı ve pozitif etkisi vardır. }\end{array}$ & $\begin{array}{l}\text { Duyguların düzenlenmesi boyutunun duygusal } \\
\text { bağlılık ve devam bağhlı̆ğı boyutlan ile ilişkisi } \\
\text { vardır }\end{array}$ \\
\hline $\begin{array}{l}\mathbf{H}_{2} \text { :Duygusal zekânın iş tatmini üzerinde } \\
\text { anlamlı ve pozitif etkisi vardır. }\end{array}$ & DESTEKLENMEDI \\
\hline $\begin{array}{l}H_{3} \text { : Kültürel zekânın örgütsel bağlllık } \\
\text { üzerinde anlamlı ve pozitif etkisi vardır. }\end{array}$ & $\begin{array}{l}\text { Motivasyonel kültürel zeka boyutunun duygusal } \\
\text { bağlllık ve devam bağhlığı boyutlan ile ilişkisi } \\
\text { vardır. }\end{array}$ \\
\hline $\begin{array}{l}\mathrm{H}_{4} \text { : Kültürel zekânın iş tatmini üzerinde } \\
\text { anlamlı ve pozitif etkisi vardır. }\end{array}$ & DESTEKLENMEDI் \\
\hline $\begin{array}{l}\text { H5: Sosyal sermayenin örgütsel bağlllık } \\
\text { üzerinde anlamlı ve pozitif etkisi vardır. }\end{array}$ & DESTEKLENDİ \\
\hline $\begin{array}{l}\text { H6: Sosyal sermayenin iş tatmini üzerinde } \\
\text { anlamlı ve pozitif etkisi vardır. }\end{array}$ & DESTEKLENDİ \\
\hline $\begin{array}{l}\text { H7: Duygusal zekânın sosyal sermaye } \\
\text { üzerinde anlamlı ve pozitif etkisi vardır. }\end{array}$ & $\begin{array}{l}\text { Başkalarını duyguların değerlendirme ve kendi } \\
\text { duyguların değerlendirme boyutlarnın sosyal } \\
\text { normlar boyutu ile ilişkisi vardır. Duyguların } \\
\text { düzenlenmesi boyutunun sosyal ağlar ve güven } \\
\text { boyutlarıyla ilişkisi vardır. }\end{array}$ \\
\hline $\begin{array}{l}\text { Hs: Kültürel zekânın sosyal sermaye } \\
\text { üzerinde anlamlı ve pozitif etkisi vardır. }\end{array}$ & $\begin{array}{l}\text { Motivasyonel kültürel zekâ boyutunun tüm } \\
\text { sosyal sermaye alt boyutlarn ile ilişkisi vardır. }\end{array}$ \\
\hline $\begin{array}{l}\text { H9: Duygusal zekânın, iş tatmini } \\
\text { üzerinden örgütsel bağlllığa etkisi vardır. }\end{array}$ & DESTEKLENMEDİ \\
\hline $\begin{array}{l}\text { H10: Kültürel zekânın, iş tatmini } \\
\text { üzerinden örgütsel bağlllığa etkisi vardır. }\end{array}$ & DESTEKLENMEDI \\
\hline
\end{tabular}

\section{TARTIŞMA, SONUÇ ve ÖNERILLER}

Küreselleşme genellikle toplumlara ve eğitim sistemlerine kültürel ve dilsel çeşitlilik getirmektedir. Sınıf içerisindeki kültürel çeşitlilik, öğrencilere kendi kültürlerinden farklı bir kültüre sahip insanları anlamak ve olumsuz önyargıları azaltmak gibi pek çok katkı sağlayabilir ve öğrenciler arasındaki etkileşim sürecini geliştirebilir. Sınıflarda etkili öğrenmeyi desteklemek ve artan kültürel çeşitliliği başarılı bir şekilde yönetebilmek için hazırlanan müfredat ve ders içerikleri ile birlikte eğitimin ana aktörü olan öğretmenlerin duygusal ve kültürel zekâ becerilerinin geliştirilmesi oldukça önemlidir.

Çalışmanın ilk hipotezi, duygusal zekânın örgütsel bağlllık üzerinde anlamlı ve pozitif etkisi olduğunu belirtmektedir. Yapılan analizlerde duyguların düzenlenmesi boyutunun duygusal bağlılık ve devam bağlılığı boyutlarıyla ilişkiye sahip olduğu ortaya konmuştur. Nikkheslat (2012) tarafından yapılan çalışmada duygusal zekânın örgütsel bağlılık üzerinde etkisi vardır ancak bu etki sadece iş tatmini ile gösterilmektedir. Atmaja vd. (2015) çalışmasındaki bulgular ise örgüt kültürü, duygusal 
zekâ ve eğitim etkinliğinin örgütsel bağlılığa anlamlı ve olumlu etkisi olduğunu ortaya koymaktadır. Başka bir çalışmada duygusal zekânın mesleki stres, iş tatmini ve örgütsel bağlılık üzerinde doğrudan ve dolaylı bir etkisi olmadığı görülmektedir (Aghdasi, Kiamanesh ve Ebrahim, 2011). Duygusal zekânın iş tatminini üzerinde anlamlı ve pozitif etkisi bulunduğunu gösteren ikinci hipotez çalışmanın sonuçlarına göre desteklenmemektedir. Duygusal zekânın iş tatmini üzerinde etkisi görülmemiştir. Fakat alanyazında çalışanların duygusal zekasının iş tatmini üzerinde pozitif etkiye sahip olduğunu belirten çalışmalar çoğunluktadır (Ahmed, 2015; Emdady ve Bagheri, 2013; Siddique vd., 2014; Tabassum, 2015; Teli ve Baba, 2017). Çalışma ortaya çıkan bu sonuç ile bahsedilen çalışmalardan ayrılmaktadır. Alan yazında çalışmayı destekler nitelikte duygusal zekanın iş tatmini ile ilişki içinde olmadığını ortaya koyan çalışmalar da bulunmaktadır (Gürbüz ve Yüksel, 2008; Çapkulaç, 2013; Akbaş, 2016)

Üçüncü hipotez, kültürel zekânın örgütsel bağlllık üzerinde anlamlı ve pozitif etkisi olduğunu belirtmektedir. Motivasyonel kültürel zekâ boyutunun duygusal bağlllık ve devam bağlılığı boyutları ile ilişkiye sahip olduğu bulunmuştur. Çalışmanın bulguları önceki çalışmaları destekler niteliktedir (Eskandarpur vd., 2013; Anvari, Irum, Ashfag ve Atiyaye, 2014; Dolatshah ve Hosseini, 2015).Bir başka çalışmada kültürel zekânın bilişsel boyutu ile örgütsel bağlılık arasında anlamlı bir ilişki tespit edilememiştir. Kültürel zekanın motivasyonel ve davranışsal boyutları ile örgütsel bağlılık arasında anlamlı bir ilişki bulunmuştur (Azarvand vd., 2013) Alanyazında kültürel zekânın iş tatmini üzerinde pozitif etkiye sahip olduğunu gösteren çalışmalar mevcuttur (Diao ve Park, 2012; Srinivas ve Patrick, 2018). Bu çalışmada ise kültürel zekânın iş tatmini üzerinde anlamlı ve pozitif etkisi olduğunu belirten dördüncü hipotez desteklenmemektedir. Şahin'in (2011) çalışmasında da liderin üst bilişsel ve bilişsel kültürel zekâ bileşenleri ile astların örgütsel vatandaşlık davranışı ve liderden kaynaklanan iş doyumu arasındaki ilişkiler bir dereceye kadar zayıf ve anlamsız çıkmıştır. Sosyal sermayenin örgütsel bağlılık üzerindeki etkisi beşinci hipotezde incelenmiştir. Sosyal sermayenin örgütsel bağlllık üzerinde anlamlı ve pozitif etkisi olduğu bulunmuştur. Önceki çalışmalar, belirtilen sonucu destekler niteliktedir (Sayadi ve Hayati, 2014; Emhan vd., 2016). Sosyal sermayenin iş tatmini üzerindeki etkisi altınc1 hipotezde incelenmiş ve sosyal sermayenin iş tatmini üzerinde pozitif etkiye sahip olduğu tespit edilmiştir. Rezaee ve Nabeiei (2016) tarafından yapılan çalışmada da iş tatmini ve sosyal sermaye arasında pozitif bir ilişki vardır ancak iş tatmini ile sosyal ilişki boyutları arasında bir ilişki bulunamamıştır.

Duygusal zekânın sosyal sermaye üzerindeki etkisi, çalışmanın yedinci hipotezini oluşturmaktadır. Başkalarının duygularını değerlendirme boyutunun sosyal normlar boyutu ile ilişkisi vardır. Duyguların düzenlenmesi boyutunun sosyal ağlar ve güven boyutlarıyla ilişkisi vardır. Kendi duygularını değerlendirme boyutunun sosyal normlar boyutu ile ilişkisi tespit edilmiştir. Önceki çalışmalarda duygusal zekânın sosyal sermaye üzerinde pozitif etkiye sahip olduğu görülmektedir (Çelik, 2014; Najafi ve Sargolzaei, 2014). Çalışmanın sekizinci hipotezinde kültürel zekânın sosyal sermaye üzerindeki etkisi incelenmiştir. Motivasyonel kültürel zekâ boyutunun tüm sosyal sermaye alt boyutları ile ilişkisi tespit edilmiştir. Fakhrerad'ın (2018) çalışmasının sonuçları sosyal sermaye ile kültürel zekâ arasında olumlu yönde anlamlı ve doğrudan 
bir ilişki bulunduğunu göstermiştir.

İş tatmini bağımlı değişkeni üzerinde duygusal ve kültürel zekânın herhangi bir etkisinin çıkmaması araştırmanın en dikkat çekici bulgularıdır. Çalışmanın kilit bağımlı değişkeni örgütsel bağlılık incelendiğinde ise duyguların düzenlenmesi ve motivasyonel kültürel zekâ boyutlarının duygusal bağlılık ve devam bağlılığı boyutları üzerinde etkiye sahip olduğu görülmektedir. Sosyal sermaye, örgütsel bağlılık üzerinde doğrudan ve anlamlı bir etkiye sahiptir. Duygusal zekâ ile kültürel zekânın örgütsel bağlılık üzerindeki etkilerini incelerken aracı değişken olarak kullanılan sosyal sermayenin herhangi bir aracılık etkisine rastlanmamıştır.

Özellikle sosyal sermaye kavramı çerçevesinde öğretmenlerin birbirleri ile yardımlaşmaları, etkin bir şekilde iletişim halinde olmaları, kendi örgütsel bağlılıklarını üst düzeyde etkilemektedir. Araştırma sonuçlarına göre, öğretmenlerin uyum ve işbirliği içinde olmaları, gerektiğinde sorumluluk almaları, kendi aralarındaki farklılıklara saygı duymaları ve yönetimin de bu örgütsel iklimi destekleyecek kararlar alması sayesinde örgütsel bağlılığın her üç alt boyutu da sosyal sermaye faktörlerinden doğrudan etkilenmektedir. İlk ve orta öğretim kurumlarında sosyal sermaye unsurlarının kullanılması, hem eğitim kalitesi üzerinde hem de iş tatmini üzerinde olumlu etkiler ortaya çıarabilir.

Duygusal ve Kültürel Zekâ boyutlarının örgütsel bağlllık ve iş tatmini üzerindeki beklenilen etkileri, bu çalışmanın sonuçlarına yansımamıştır. İleride yapılacak çalışmalarda farklı ölçeklerin kullanılması, farklı örneklem gruplarının çalışmaya dahil edilmesi ile mevcut çalışmadan farklı sonuçlar elde edilebilir. Bu çalışmada öğretmenlerin ankette yer alan zekâ türlerinin ehemmiyetini fark edememiş olmaları da muhtemeldir.

Duygusal ve kültürel zekânın iş tatmini üzerinde bir etkiye sahip olmaması Maslow’un ihtiyaçlar hiyerarşisi teorisi ile açıklanmaktadır. Maslow'un ihtiyaçlar hiyerarşisi teorisi, iş tatmini ile ilgili teorilerden biridir. Maslow, en alt düzeydeki ihtiyaçların fizyolojik ihtiyaçlar ve güvenlik olduğunu, en üst düzeydeki ihtiyaçların ise kendini gerçekleştirme olduğunu belirtmektedir. Duygusal zekâ yeteneğine sahip bir kişinin kendini gerçekleştirme düzeyine geldiği söylenebilir. Maslow'un belirttiği gibi alt düzeydeki ihtiyaçlar karşılanırsa üst düzeydeki ihtiyaçlar kendini göstermektedir. Bu nedenle iş ortamında ücret, çalışma koşulları, iş güvenliği, saygı gibi ihtiyaçlar karşılanmazsa daha yüksek düzeydeki ihtiyaçlardan çalışanlar tatmin olmayabilirler (Aghdasi vd., 2011). Bu temel koşullar, kamu kurumlarında çalışan öğretmenler açısından da benzer bir sıralamada geçerlidir. Çalışma kapsamında ortaya çıkan bu bulguların eğitim sektörünü kapsayacak şekilde genellenebilmesi en kritik husustur. Günümüzde duygusal ve kültürel zekâ, uzmanlar tarafından iş tatmini ve örgütsel bağlılığı artırmanın çözümlerinden biri olarak kabul edilmektedir. Ancak alt düzey ihtiyaçların karşılanması ve bu kavramlarla ile ilgili yeterli farkındalık sağlanması oldukça önemlidir. Duygusal ve kültürel zekânın eğitim programlarına yansıtılması, eğitim ortamlarında bu kavramlar ile ilgili farkındalık kazandırılabilmesi için uygun strateji, yöntem ve araçların oluşturulması, daha fazla bilimsel çalışmaların yapılmasının yararlı olacağı düşünülmektedir. 
Çalışma sonucunda özellikle karar alıcılar için aşağıdaki öneriler geliştirilmiştir:

-Eğitimler ve geliştirme programları ile hedeflenen tutum ve davranışlarda olumlu değişimler görülmektedir. Araştırma bulgularının da desteklediği gibi öğretmenlere sosyal sermayelerini artırmada önemli araçlardan olan duygusal ve kültürel zekâyı geliştirici pratiğe dayalı eğitimler verilmelidir.

-Öğretmenler işte karşılaşılan sorunları ve duygusal zorlukları rahatça paylaşabilecekleri konusunda teşvik edilmelidir. Mesleğe yeni adım atan genç öğretmenler kendilerine rehberlik yapabilecek tecrübeli ve uzman meslektaşları tarafından desteklenmelidir.

-Öğretmenlerin daha girişken ve üretken olabilmeleri için güven ve destek ortamları oluşturulmalıdır. Öğretmenlerin birbirleriyle ve çevreleriyle daha yakın ve sıcak ilişkiler kurabilmeleri için etkinlikler (yemek toplantıları, geziler) düzenlenebilir.

-Eğitim ve öğretim alanında yeni nesil teknikler kurumlara adapte edilmelidir.

\section{KAYNAKLAR}

Aghdasi, S., Kiamanesh, R. A., \& Ebrahim, N. A. (2011). Emotional intelligence and organizational commitment: Testing the mediatory role of occupational stress and job satisfaction. Procedia-Social and Behavioral Sciences, 29, 1965-1976. https://doi:10.1016/j.sbspro.2011.11.447.

Ahmed, H. (2015). Emotional intelligence and job satisfaction among university teachers. International Journal of Educational Studies, 2(2), 95-100.

Akbaş, Ö. (2016). İstanbul Bakırköy Bölgesi Kamu Hastaneler Birliğinde çalışan fizyoterapistlerde duygusal zekâ ve iş doyumu ilişkisi. (Yüksek Lisans Tezi ).İstanbul Gelişim Üniversitesi Sosyal Bilimler Enstitüsü.

Akomolafe, J. M., \& Ogunmakin, O. A. (2014)." Job satifaction among secondary school teachers: Emotional intelligence, occupational stress and self- efficacy as predictors". Journal of Educational and Social Research, 4(3), 487-498. https://doi:10.5901/jesr.2014.v4n3p487.

Aküzüm, C., Tan, Ç. (2014). Social capital and job satisfaction as the predictor of the organizational commitment. International Journal of Social Sciences and Education, $4(3), 729-742$.

Anari, N. N. (2012). Teachers ' emotional intelligence, job satisfaction and organizational commitment. Journal of Workplace Learning, 24(4), 256-269. https://doi.org/10.1108/13665621211223379.

Anvari, R., Irum, S., Ashfaq, M., \& Atiyaye, M. D. (2014). The impact of leader's cultural intelligence on organizational commitment. Asian Social Science, 10(7), 45-51 https:// doi: $10.5539 /$ ass.v10n17p45.

Atmaja, S. M., Hardhienata \& Sunaryo, W. (2015). The effect of organizational culture, emotional intelligence and training effectiveness to organizational commitment. International Journal of Managerial Studies and Reseach, 3(4), 40-45.

Azarvand, J., Feizi, M., \& Alipour, H. (2013). Surveying the relationship between cultural intelligence and organizational commitment at Islamic Azad University. Arabian Journal of Business and Management Review, 3(3), 78-84. 
Barclay, D., Higgins, C., \& Thompson, R. (1995): The Partial Least Squares (PLS) Approach to Causal Modelling: Personal Computer Adoption and Use as an Illustration, Technology Studies, 2(2), 285-309.

Charsoughi, T. B., Abedi, R. M., \& Nilforoushan, P. (2015). The effect of emotional intelligence group traning on human and social capital in Isfahan University of Technology. International Letters of Social and Humanistci Sciences, 50, 91-99. https://doi.org/10.18052/www.scipress.com/ILSHS.50.91

Claridge, T. (2004). An important role for social capital?. (Master's thesis). The University of Queensland,

Coşkun, R., Altunışık, R., Bayraktaroğlu, S., ve Yıldırım, E. (2015). Sosyal Bilimlerde Araştırma Yöntemleri SPSS Uygulamalı (8. baskı). Sakarya: Sakarya Yayıncılık.

Çapkulaç, O. (2013). Yöneticilerin duygusal zeka düzeylerinin iş tatmini ve iş performans algısı üzerine etkisi. (Yüksek Lisans Tezi). Akdeniz Üniversitesi Sosyal Bilimler Enstitüsü.

Çelik, N. (2014). The effect of the level of the emotional intelligence of the employees who are employed in family business on the social capital structure. European Journal of Research on Education, 2, 134-141. https://doi: 10.15527/ejre.201426569

Dhani, P., \& Sharma, T. (2016). Emotional intelligence; history, models and measures. International Journal of Science Technology and Management, 5(7), 189-201.

Diao, A., \& Park, S. (2012). Culturally intelligent for satisfied workers in a multinational organization: Role of intercultural communication motivation. Africa Journal of Business Management, 6(24), 7296-7309. https:// doi: 10.5897/AJBM11.2424

Doğan, N. (2009). Sinı öğretmenlerinin duygusal zekâları ile örgütsel bağlılıkları arasındaki ilişki: İstanbul İli Anadolu Yakası Örneği. (Yüksek Lisans Tezi) Maltepe Üniversitesi Sosyal Bilimler Enstitüsü.

Dolatshah, A., \& Hosseini, G. M. (2015). The relationship between cultural intelligence and organizational commitment and burn out among employees of the Arman Financial Institution. European Online Journal of Natural and Social Sciences, 4(1), 1298-1306.

Duru, S. E. (2020). Kültürel zekânın iş ve yaşam tatmini üzerindeki etkisi. (Yüksek Lisans Tezi). Marmara Üniversitesi Sosyal Bilimler Enstitüsü.

Emdady, M., \& Bagheri, N. (2013). The relationship between emotional intelligence and job satisfaction. European Journal of Experimental Biology, 3(1), 554-558.

Emhan, A., Tongur, A., \& Türkoğlu, İ. (2016). An analysis of the social capital, organizational commitment and performance in the public sector of southeastern Turkey. Transylvanian Review of Administrative Sciences, 47, 49-62.

Erbaşı, A., \& Sanioğlu, Z. (2016). Sosyal sermayenin örgütsel bağlılık üzerindeki etkisinde örgüt depresyonunun aracılık etkisi.Balkan Journal of Social Sciences/ International Congress of Management Economy and Policy, 2016 Aralık, 860-867.

Eskandarpur, B., Nazari, I., Vejdan, R., \& Tohidi, A. (2013). The study of the relationship between cultural intelligence and organizational commitment. Journal of Basic and Applied Scientific Research, 3(1), 823-829.

Fakhrerad, P. (2018). Recognition of the relationship between social capital and cultural intelligence among employees of Tehran Abfar Company. Amazonia Investiga, 7(16), 184-195. 
Goleman, D. (1995). Duygusal zekâ neden IQ'den daha önemlidir? (Emotional intelligence: Why it can matter more than IQ) (Çev. B. Ş. Yüksel). İstanbul: Varlık.

Gudmundsson, G., \& Mikiewicz, P. (2012). The concept of social capital and its usage in educational studies. Studia Edukacyjne, 22, 55-79.

Günkör, C. (2016). Öğretim elemanlarının sosyal sermaye ve eğitim ortamına ilişkin algıları: Gazi Eğitim Fakültesi Örneği. (Doktora Tezi). Gazi Üniversitesi Eğitim Bilimleri Enstitüsü.

Gürbüz, S., Yüksel, M. (2008). Çalışma ortamında duygusal zekâ: İş performansı, iş tatmini, örgütsel vatandaşlık davranışı ve bazı demografik özelliklerle ilişkisi. Doğuş Üniversitesi Dergisi, 9(2), 174-190.

Gürbüz, S., Şahin, F. (2016). Sosyal Bilimlerde Araştırma Yöntemleri (3. baskı). Ankara: Seçkin Yayıncılık.

Gürkan, Çetin, G. (2006). Örgütsel bağhllık: Örgütsel iklimin örgütsel bağlllık üzerindeki etkisi ve Trakya Üniversitesi'nde örgüt iklimi ile örgütsel bağhllık arasındaki ilişkinin araştırılması. (Yüksek Lisans Tezi). Trakya Üniversitesi Sosyal Bilimler Enstitüsü.

Güvercin, S. (2020). Kamu kurumların çalışan sağlık yöneticilerinin duygusal zekâlarının iş tatminine etkisi. (Yüksek Lisans Tezi). Yeditepe Üniversitesi Sağlık Bilimleri Enstitüsü.

İnan, K. (2017). Türkçe öğretmeni adaylarında kültürel zekânın çeşitli değişkenlere göre incelenmesi. Hacettepe üniversitesi Yabancı Dil Olarak Türkçe Araştırmaları Dergisi, 3. 21-33.

İşler, Büyüker, .D., Atilla, G. (2013). Duygusal zekâ ve dürtüsel satın alma davranışı ilişkisi. Selçuk Üniversitesi İktisadi ve İdari Bilimler Fakültesi Sosyal ve Ekonomik Araştırmalar Dergisi, 26, 180-206.

Jafari, H. (2013). Managers' cultural intelligence and social capital and performance: A case study of cultural institutions. Journal of Basic and Applied Scientific Research, 3(4), 802-809.

Kabar, M. (2017). Lise öğretmenlerinin işe bağhllık düzeyleri ile duygusal zekâ düzeyleri arasındaki ilişki. (Yüksek Lisans Tezi). İstanbul Sabahattin Zaim Üniversitesi Marmara Üniversitesi Eğitim Yönetimi ve Denetimi Ortak Yüksek Lisans Programi.

Koç, F., Kaya, N., Özbek, V., ve Akkılıç, E. M. (2014). Algılanan fiyat ile tüketici güveni arasında algılanan hizmet kalitesinin aracı etkisi: Bankacılık ve GSM sektörlerinin karşılaştırılmasına yönelik bir araştırma. Pazarlama ve Pazarlama Araştırmaları Dergisi, 13, 1-26.

Korkmaz, K. A. (2018). Duygusal zekânın örgütsel bağlılık üzerine etkisinin incelenmesi. (Yüksek Lisans Tezi). Bahçeşehir Üniversitesi Sosyal Bilimler Enstitüsü.

Köybaşı, F., Uğurlu, T. C. ve Güner, G. A. (2017). Okulların sahip oldukları sosyal sermayeye ilişkin öğretmen görüşleri. YYÜ Eğitim Fakültesi. Cilt:14, Sayı:1, 102-122

Kuchy, A. S., Thilagavathy, T. (2017). "Study of emotional intelligence among high school teachers". International Journal of Advanced Research and Development, 2(6), 757-760.

Kuşluvan, Z., ve Kuşluvan, S. (2005). Otel işletmelerinde iş ve işletme ile ilgili faktörlerin iş tatmini üzerindeki görece etkisi: Nevşehir Örneği. Anatolia: Turizm Araştırmaları Dergisi, 16(2), 183-203. 
Milli Eğitim Bakanlığı. (2019). Milli Eğitim İstatistikleri Örgün Eğitim 2018-2019. Strateji Geliştirme Başkanlı̆̆1 . MEB. Erişim Adresi: Resmi İstatistikler (meb.gov.tr), Erişim Tarihi: 20.09.2021.

Molina, C. S. (2013). Romanticizing culture: The role of teachers' cultural intelligence in working with diversity. The Catesol Journal, 24(1), 220-244.

Mondal, A., \& Saha, B. (2017). Job satisfaction of secondary school teachers in relation to personality and emotional intelligence. American Journal of Education Research, 5(10), 1097-1101. https://doi:10.12691/education-5-10-11.

Najafi, A.,\& Sargolzaei, A. (2014). Investigating the effect of emotional intelligence and social capital ob the performance of employees in Zabol University of Medical Sciences. World Journal of Environment Biosciences, 6, 96-104.

Narasimhan, P. (2018)." A study on emotional intelligence and job satisfaction among school teachers". The International Journal of Indian Psychology, 6(2), 59-67. https://doi: 10.25215/0602.007.

Nikkheslat, M., Saleki, S. Z., Asgharian, R., \& Hojabri, R. (2012). The relationship between emotional intelligence and organizational commitment: The mediating role of job satisfaction. International Journal of Research in Management $\mathcal{E}$ Technology, 2(5), 495-498.

Özan, B. M., Özdemir, Y. T. ve Yaraş, Z. (2017). The effects of social capital elements on job satisfaction and motivation levels of teachers. European Journal of Education Studies, 3(4), 49-68. http://doi:10.5281/zenodo.344895

Özmen, F., Aküzüm, C., Koçoğlu, E., Tan, Ç., ve Demirkol, M. (2014). Eğitim kurumlarında sosyal sermayenin iş tatmini üzerindeki etkisi. Ekev Akademi Dergisi, 18(58), 333-346.

Petrovic, S. D. (2011). “How do teachers perceive their cultural intelligence?”. Proceida Social and Behavioral Sciences, 11, 276-280.

https://doi:10.1016/j.sbspro.2011.01.076

Rezaee, R., \& Nabeiei, P. (2016). Job satisfaction and social capital in university teachers. Journal of Health Management \& Informatics, 3(2), 46-50.

Rostami, M., Ghazvini, H. M., Farmani, M., \& Saraei, A. (2013). Relation of organizational social capital with job satisfaction and job stres: An empirical investigaiton.. Journal of Basic and Applied Scientific Research, 3(3), 578-583.

Rust, A. D. (2014). Relationship between the emotional intelligence of teachers and student academic achievement. ( Doctoral dissertation.). University of Kentucky

Sale, Z. (2014). The relationship between personality, cognition abd emotional intelligence. ( Master's thesis). The University of South Africa.

Sauer, K. (2008). A comparison of cultural intelligence between black and white South African leaders. (Master's thesis). The University of Pretoria,

Sayadi, E., \& Hayati, A. (2014). The relationship between social capital and organizational commitment of employees in Zanjan education organization: (A case study). International Journal of Academic Research in Economics and Management Sciences, 3(5), 166-177. https://doi: 10.6007/IJAREMS/v3-i5/1219

Siddique, S., Riaz, F., Siddique, A., Riaz, A., Nawaz, Y., \& Shehzadi, S. (2014). Role of emotional intelligence on job satisfaction in university teachers. Academic Journal of Interdisciplinary Studies, 3(6), 327-332. https:// doi:10.5901/ajis.2014.v3n6p327 
Srinivas, S., \& Patrick, A. H. (2018). Role of organizational cultural intelligence and its influence on employee job satisfaction among process associates in financial TNCs in Bangalore. International Journal of Pure and Applied Mathematics, 119(15), 1607-1617.

Şahin, F. (2011). Liderin kültürel zekâsının astların örgütsel vatandaşlık davranışı ile iş doyumu üzerine etkisi. Savunma Bilimleri Dergisi, 10(2), 80-104.

Şahin, S., Aydoğdu, B., ve Yoldaş, C. (2011). Duygusal zekâ ve iş doyumu arasındaki ilişkiler: Eğitim müfettişleri üzerinde bir araştırma. İlköğretim Online, 10(3), 974990.

Tabassum, N. (2015). A study of correlation between emotional intelligence and job satisfaciton of secondary school teachers. Scholarly Research Journal for Humanity Science E English Language, 2(10), 2508-2513.

Teli, R. M., \& Baba, M. M. (2017). Examining the impact of emotional intelligence on the job satisfaction of teachers. Asian Journal of Managerial Science, 6(2), 16-20.

Ulusoy, H. (2017). Turist rehberlerinin kültürel zekâ düzeyi ve öz yeterlilik inançlarının hizmet sunumuna etkisi. (Yüksek Lisans Tezi). Balıkesir Üniversitesi Sosyal Bilimler Enstitüsü.

Yüksel, A., ve Ereş, F. (2018). The correlation between global citizenship perceptions and cultural intelligence levels of teachers. Universal Journal of Educational Research, 6(5), 1069-1076. https://doi: 10.13189/ujer.2018.060528 